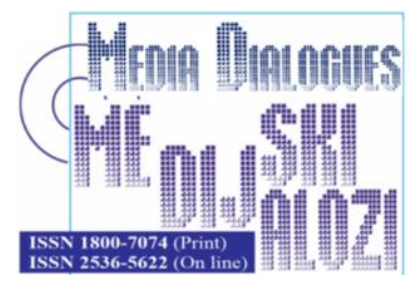

Spaic, A. (2021), ,Syndicourt - TV Reality Show and Forum of Arbitration”, Media Dialogues / Medijski dijalozi, Vol. 13, No. 3, pp. 25-34.

\title{
Syndicourt - TV Reality Show and Forum of Arbitration
}

\author{
Associate Professor ANETA SPAIC \\ University of Montenegro, Faculty of law, \\ Podgorica, Montenegro
}

\begin{tabular}{|c|c|c|}
\hline$A \boldsymbol{R} \boldsymbol{T} \boldsymbol{C} \boldsymbol{L} \boldsymbol{E}$ & Received: December 21,2011 / & Revised from: January 23, 2020 \\
$\boldsymbol{I} \boldsymbol{N} \boldsymbol{F} \boldsymbol{O}$ & Accepted: February 23, 2020 / & Available online: July 15, 2020 \\
\hline DOI & doi.org/10.14254/1800-7074/13-3/2 \\
\hline
\end{tabular}

\begin{abstract}
Relationship between the media and the law is often seen as very problematic, especially if viewed from the perspective of media as one of the main channels for the acquisition of basic knowledge on elements of the legal system. In this paper we will analyze the elements of the TV reality show - syndicourt, daily broadcasted in a country known for one of the largest and strongest legal system - the United States. Through many of these TV reality show, law is strongly present in everyday life, and such media presentation of law is of crucial importance in creating the public perception of how the legal system works. The most common problems related to the impact of dis- torted media representation of law through reality show is generation of the obvious tendency of the audience to rely on the perception of the media, especially when it comes to issues with which the public rarely comes in contact in real
\end{abstract}


life. This article submits that this program has become the important factor in the legal education of the lay public, and therefore, it has to be treat-ed as such.

KEYWORDS: Reality show, arbitration, media law, court procedure, education, communications.

\section{INTRODUCTION}

A number of different reality TV shows increasingly and intensively permeate our everyday lives. We spend hours daily lives viewing a variety of entertaining, inspiring, educational, and well-conceptualized tv shows. Why did reality tv show become such a phenomenon, so that in many countries more people voted for contestants of the shows than for candidates in general elections? (Johnson Woods, 2002, pp. 1-34).

There are several reasons why people become engrossed with different reality shows. These shows, for example, help people solve their concrete, tangible and some- times serious problems, transform existing problems, relationships, and places into a platform of fun, game and relaxation, and educate audience on different life issues. Big Brother, Servivor, Drug Addicts (Celebrity Rehab and Intervention exist), Feigning Survival, Spoiled Debutants, Little People, Cakes, Singers and Dancers, Real (Loud and Obnoxious) Wives, Looking for Love, Pregnant Teens, The Young and Wasted are reality shows taking place on different tv channels in countries all over the world, being more or less justified in their existence. There are also the reality shows which present a mix of reality, entertaining and educational elements, and those that have received increasing attention across multiple disciplines, with a focus on the legal profession. In this, so called 'juridico - entertainment complex', in last twenty years media has through the number of different TV reality programs entwined with law. Some of them, including The Law Firm, The Verdict, Terrorism in the Hands of Justice, Bailiffs, Crimewatch, Clamper, People's Court, have contributed to the trend of strongly shaping the legal knowledge of the lay public (Brenner, 2005, pp. 1-2; Brett Bell and Odysseos, 2002, pp. 1-13). Thus, these shows in entertainment media provides the strongest and most effective way of influencing the average citizen's views on legal concepts and issues.

There is a strong contention that media constitutes main channel of people's learning and perceiving the law (Gies, 2008, p. 73). However, media's investment in law is often perceived as deeply problematic. In the midst of that concern is the influ-ence exerted by media on the public. Namely, media with its flawed understanding of law relies on the assumption that originally people have very scant and poor knowledge of the legal system. This, furthermore, triggers the issue of relevance of law in everyday life, and therefore the necessity of defining how big and adequate the role of media is. In this article we will analyze one of the most discussed legal 
and entertaining sides of the reality show very well accepted in the USA, called syndicourts. Unlike many of other previously mentioned shows that some might seen as a post-modern art form analyzed in its natural state, unaffected by plot, syndicourts are diagonally opposite. These TV shows are fully prepared, affected by the precise complex structu- re scenario, with detailed focus on the judge, parties, rules of the procedure, language used, and behavior of the parties.

\section{SYNDICOURTS - TV REALITY SHOW}

Syndicourts, portrayals of litigation through the paradigm of the reality show producer, are adjusted to the myriad viewers' attitudes. Namely, they present the syndicated television courtroom. Due to its ubiquity and digestibility, syndicourts, through the shows such as Judy Judge and People's court exerts public's perception of litigation, its processes, and actors, earning tremendous popularity. The first question that may occur in that perspective is why and how the syndi-courts gain that popularity within the USA. What created the program's phenomenal mass appeal? The answer can be found within the hidden part of the relationship between media and expensive state court system that has limited public access. With respect to it, in the United States of America, the right of media to attend trials is not as, it to be expected, seen through the Sixth Amendment which provides that trials shall be public, but by First Amendment guaranteeing the freedom of speech and press. Although expressly stipulated, it took decades for the US Supreme Court to undoubtfully de- clare that press has a right to attend trial, in the Waller case (Waller v. Georgia, 467 U.S. 39, 1984), which stated that four conditions must be met in order to close the trial to the public as well as the media ${ }^{1}$. Nevertheless, allowing the members of the media to be present in the courtroom does not mean that they have permission to make audio-visual recordings. Furthermore, while the practice differs among the states, the Rule 53 of the Federal Rules of Criminal Procedure clearly prohibits any broadcasting from the courtrooms. Majority of the professionals in the judiciary argue that this approach is useful in order to avoid trial by media and sensationalism. But they might be on wrong path. Namely, by closing door to media in the courtrooms (Schwartz, 2011, pp. 146-169), they left the enormous space for malfeasance and wrong interpretations, and open the door for the entertainment business to try to present it in their superficial and, sometimes, nebulous way. Therefore, the public's interest to satisfy its hunger for the information will be fulfilled in one or another way: by allowing broadcasting from the courtrooms or generating TV reality shows which imitate real courtrooms. However, the answer to explanation of this contention is not simple, on contrary.

\footnotetext{
1 These requirements are: the party seeking to close the hearing must advance an overriding interest that is likely to be prejudiced; the closure must be no broader than necessary to protect that interest; the trial court must consider reasonable alternatives to closing the proceeding; and it must make findings adequate to support the closure
} 
In several cases the Supreme Court has held that a state has the right to allow television cameras into courtrooms (Chandler v. Florida, 449 U.S. 560, 571, 1981). The OJ Simpson murder trial was broadcasted entirely. However, surprisingly, there was not expressed interest of the public to watch it. So, what does the lay public really want to watch? Digested, short, and interesting parts of the trial cleaned from the boring legal aspects of such procedure and presented as a court drama? In response to the public's desire to watch interesting and funny court trials, production houses were given the idea of creating the reality television shows of tremendous popularity, called syndicourts.

The term syndicourt ${ }^{2}$ derives from the word syndication which is the practice of selling rights to television programs either local TV stations or cable channels (Biederman, 2007, pp. 859 -861). As such, syndicourt was first introduced to the American audience in 1981 with the substantive difference relative to the previous similar shows such as Traffic Court (1957) and People's Court of Small Claims (1959). However, these shows aired prior to syndicourt, presented fictional or reconstructed real court cases. Syndicourt is the first reality court show that did not use actors, but showed the actual cases with the actual parties involved.

This TV court is designed as arbitration proceedings, with the final and binding decision upon the parties. The program always starts with the opening monologue of the narrator declaring that the show is real, that the participants are not actors, but actual litigants with a case pending in civil court. He also says that both parties have agreed to drop their claims and have their cases settled in the procedure of syndicourt $^{3}$. It deals in small claims matters. When the show was premiered in 1981, litigants could not sue for more than US $\$ 1,500$, which was the limit for small claims court at the time in California. As the laws changed, so did this amount. In 1993 the litigants already could sue for up to US $\$ 5,000$, which is now the law in most states. Today, the small claims court deals with matters up to US\$7,500 (depending on the statutory maximum in the claimant's state) ${ }^{4}$.

How the parties are recruited? There are several ways of finding the parties for the show. Through the websites of the TV shows, people with the small claim cases are given the chance to apply for the TV show and try to resolve their disputes. In

\footnotetext{
${ }^{2}$ Syndicourt is produced by A Ralph Edwards-Stu Billett Production, where distribution rights today belong to Warner Bros. Television Distribution. British version of the syndicourt reality show was produced by SMG TV Production. However, this show wasn't very popular so that in 2005 the show ceased and it was not re-aired.

${ }^{3}$ This is the latest opening that was revealed recently, in 2009. When the original People's Court first hit the air, the opening monologue was:"What you are about to witness is real. The participants are not actors. They are the actual people who have already either filed suit or been served a summons to appear in a California municipal court. Both parties in the suit have agreed to dismiss their court cases and have their disputes settled here, in our forum: The People's Court."

${ }^{4}$ Another case during the second-season premiere featured a US $\$ 15,000$ lawsuit based upon the laws of the state of Florida. On the Marilyn Milian version of the show, one case featured the plaintiff having four separate lawsuits against the defendant for a total of US $\$ 20,000$
} 
addition to it, researchers of the show would examine small claims filings and approach the future parties - plaintiff and defendantin interesting cases. Then, the researchers present the producer's offer to have their dispute resolved by the judge/ arbitrator for free, as long as they would agree to dismiss their action and be bound by judge/arbitrator's decision.

Therefore, the incentives to the parties to resolve their disputes in public are clear. The losing party does not actually need to pay the judgment. The system of paying the appearance fee varies. ${ }^{5}$. Usually, the production company pays the judgment on behalf of losing party. However, both parties do have to have some kind of monetary compensation - appearance fee, for involvement in the show. Namely, at the very end of each shown is the disclaimer explaining the incentives to the parties to appear in the show and therefore determining the nature of the proceedings: "Both the plaintiff and the defendant have been paid from a fund for their appearance. The amount, if any, awarded in the case, is deducted from this fund, and the remainder is divided equally between both litigants. The amount of the fund is dependent on the size of the judgment. No information is given as to what relation the amount of the fund bears to the size of neither the judgment, nor the amount of the fund if a verdict for the de- fense is rendered." The syndicourt TV show is very much structured and even the smallest detail has been arranged by the producer ${ }^{6}$, with the intention of simulating the courtroom with the all possible tools of having the arbitrator dressed in judge's rope, having the narrator, the bailiff and audience, giving to it the public tone.

\section{SYNDICOURTS - FORUM OF ARBITRATION}

For the purpose of determining the nature and the way of functioning of the syndicourts it is indispensable to convey several most important features of the legal technique for the resolution of the disputes outside the court. Namely, that technique is a form of alternative dispute resolution (ADR),called arbitration (Scott Rau, 2005, pp. 10-12). Arbitration (arbitral tribunal), as non-state institution, consists of one or three arbitrators which are, by the parties, granted the power to decide upon the their dispute. The arbitrators enjoy immunity from liability for anything done or omitted, unless they act in bad faith. So one of the most important feature of arbitration is that arbitrators are chosen by the parties themselves. Furthermore, the award made by them (impartial third party) will be final and binding. Namely, the arbitration procedure is a single stage procedure which means that arbitration award finally resolves the dispute, and it is binding and enforceable from the time it is published to the par-

\footnotetext{
${ }^{5}$ Sometimes, it can be organized in the following manner: Both parties are paid from a fund. This fund is based on the amount of the lawsuit claim, but an exact formula is not stated. The fund is to be first divided equally, and then any monetary judgment ordered is subtracted from the loser's half.

${ }^{6}$ In despite to it, the broadcasted episodes are sometimes mistakenly divided in a different order from which they are taped. This is why the judge's clothes change and why there is different audience.
} 
ties. International law not only does not provide for legal remedies against this kind of award.

In theory, arbitration is a consensual process, and the parties cannot be forced to resolve dispute through arbitration unless they in writing agree to do so. Also, arbitration parties may determine what substantive law will apply in their dispute, becau- se this is one of the reasons for referral to arbitration rather than state court. It is also extremely important to emphasize that the parties can decide on what procedural law will apply in the arbitration proceedings. This means that they are autonomous from this perspective, too. However, even when there is a written consensus, the subject matter of some disputes is not capable of arbitration ${ }^{7}$. Determination of the eligibility of the dispute to be resolved through arbitration is called arbitrability. Namely, the disputes about the rights which the parties may freely dispose of, can be resolved through arbitration. On the other hand, the disputes about the status of individuals, disputes governed by antitrust law, unfair competition disputes, regulation of securities have to be excluded from arbitration. Therefore, unless both conditions are met the procedure can be validly initiated.

When speaking about the costs of the arbitration, arbitral tribunals award legal costs in relation to the determination of the dispute, i.e. against the losing party, just as it is customarily done in regular courts.

In addition to the above-stated reasons why the parties often resort to this technique of resolving disputes, there are two more perceived potential advantages over judicial proceedings:

- Firstly, one of the crucial reasons for making the parties resolve their dispute through arbitration is the confidentiality of the process. It is assumed that the public in a legal case could jeopardize the reputation and business so that parties afraid of such a consequences often resort to the arbitration. Publication of arbitration awards, primarily in the case of institutional arbitration, can be implemented only with the explicit consent of the parties and with the approval of the President of the Court of Arbitration.

- Secondly, as previously mentioned, the important advantage of this kind of proceeding is the speed of arbitration. The slowness of the civil judicature is common denominator of many national legal systems. An ideal place for a quick resolution of the dispute is arbitration. It does not assume the formalities immanated into the judicial procedure. On the contrary there is cooperation of the parties and even the decision can made just based on the writings.

\footnotetext{
${ }^{7}$ Arbitration is often used in the area of international commercial disputes, in consumer and employment matters
} 


\section{SYNDICOURTS - THE MIXTURE OF BOTH: TV REALITY SHOW AND ARBITRATION}

As from the definition of the syndicourts we learned that these proceedings are arbitration. However, the above provided brief introduction to the arbitration as the ADR technique of resolving disputes and the analysis of the particular elements of the syndicourt would be useful from the perspective of understanding the nature of this tv reality show. Just as in arbitration, the procedure is initiated by parties having the agreement signed. By signing the agreement the parties grant the jurisdiction to the judge / arbitrator to adjudicate the dispute between parties. In addition to it, by signing the agreement, they agree not only to withdraw the claim before the courts, but to respect the final and binding decision of the judge as defined under arbitration.

The judge in syndicourt does not have any personal liability regardless of how he or she conducts the arbitration. However, just as in arbitration, the arbitrability of the dispute has to be questioned before, during, or after the procedure. There were some of the shows where the arbitrator, ex judge, have decided upon the case which had to be brought before the state courts, and resolved within its exclusive jurisdic$\operatorname{tion}^{8}$. However there are a number of the characterists of the syndicourts which differ from the elements of the arbitration procedure. Namely these are the tricks that the producers of the syndicourts used to manipulate and seduce the audience for the purpose of gaining tremendous popularity.

- Firstly, the sets of the syndicourts are designed as the ordinary courtroom. Producers of the shows use TV tools in creating the aura of the actual courtroom, having the arbitrator dressed as a judge in a ropes and gavel. They create a physical layout which is the feature of the courtroom. The setup simulates a regular trial instead of normal arbitration proceedings where the arbitrator sits with the parties around the conference table without any audience present. Therefore, syndicourt imi- tates the courtroom, and not the arbitration procedure.

- Secondly, the behavior of the judge is something that can be seen as the most problematic from the both perspective - of the real judge from the courtroom and the arbitrator. The tone of the judge is, at many occasions very rude, mean, and intolerant. The more she is brazen to the unlikable litigant, the more she is popular and well-paid because her ratings are better ${ }^{9}$. In ordinary court or arbitration procedure that kind of conduct could not be tolerable. The judge would be challenged and therefore repla- ced for such a kind of misconduct.

\footnotetext{
${ }^{8}$ In B.M.v. D.L. case on the issue of child custody, the Family Court of Kings Country, New York, overturn the decision of the syndicourt - Judy Judge.

${ }^{9}$ Syndicourt with Judge Judy is one of the 10 top of syndicated programming. Syndicourt with Judge Joe Brown has almost 4.0 million viewers per week.
} 
- Thirdly, although not rigorous and taught as court procedures, there are substantive and procedural rules that do have to be obeyed by the institutional or even ad hoc arbitration institutions. In syndicourts there are neither substantive nor procedural rules which have to be considered, and therefore there is no legal security and certain- ly, which is the main feature of any legal situation.

- Fourthly, the issue that might appear different in comparison to the arbitration procedure is that cost including the cost of judgment will be borne by the pro- duction house, and not by the parties. In the beginning, this was the crucial reason not to consider syndicourts as arbitration. This contention for the first time was raised and confirmed in the Doo Wop Shoppe Ltd. v Ralph Edwards (691 N.Y.S.2d 253 1998). However, just two years later in Kabia v. Koch (713 N.Y.S.2d 250 2000), this issue was interpreted very differently. In accordance with the rules with of the leading arbitration institutions, there was nothing to prevent syndicourt from adopting the practice of bearing the costs of judgment, and still be called arbitration.

- Fifthly, another important feature of the syndicourt that may appear problematic is the requirement of confidentiality as the main advantage of arbitration proceedings. Syndicourt's procedure of resolving disputes is public, and designed in the manner that as more people have seen it, the more it is successful. Therefore, the main feature of arbitration as confidential does not apply to this tv show process of resol- ving disputes.

Therefore, there are number of the elements of syndicourts shows that can be seen similar to those immersed in the authentic arbitration procedure. Nevertheless there are those opining the nature and main advantages of this technique of resolving disputes such as the confidentiality issue.

Among all the presented problematic features of the syndicourt procedure is related to the sets of the syndicourts as courtrooms, with judges dressed in robes and gavels, bailiff and narrator as well as the present audience. The physical layout that resembles regular court procedure misleads the public and contributes to the public's potentially wrong understanding of the functioning of the legal system. Admittedly, at the end of the show there is the disclaimer pointing out that portions of the pro- $g$ ram have been edited to conform to time or content restrictions, and that the show is an arbitration, and not litigation ${ }^{10}$. However, this disclaimer flashed on the screen lasts for a fragment of a second, making it impossible to read without videotaping and freeze-framing the image. Therefore, in order to fairly and honestly treat audience, there is a strong need to make the content of disclaimer more available to the eye of a viewer.

\footnotetext{
${ }^{10}$ In Judge Judy, Judge Joe Brown, The People's Court, and Texas Justice, disclaimers are arranged so that it is impossible to read them, because of the speed they come onto the screen and because of their very small font. Only upon taping an episode and using the pause button was it possible to read it
} 


\section{CONCLUSION}

Through a number of the tv shows, law is strongly involved in the people's daily life, hence the television representation of the law has the crucial impact on the public's perception of how the legal system works ${ }^{11}$. The most common concerns about the effects of distorted media portrayals of law, stem from the perception that audience is easily being duped by the media. The risk is exacerbated assuming the lack of the legal experience of the audience which make them highly dependent on media sources. There is visible propensity to rely on media to broaden our horizon and gain exposure to phenomena and ideas we rarely come into contact in the real life (Gies, op.cit., p. 134.).

It is uncontested fact that these shows became very significant factor in the legal education of the lay public. Nevertheless, if analyzed carefully it can be seen as a potential danger, directing the public into a misconception of what is law and how it functions. While the syndicourts can be undoubtedly considered as an entertaining television program, they do not accurately depict what they pretend to appear as, i.e., the regular courtroom. Misrepresentation of the actual court system can have dangerous and tremendous effects on the viewing public. Therefore, it seems indispensable for these purposes, to legally bound the producers to obviously convey the distinction between the show and the real courtroom ${ }^{12}$, just in order not to misguide the public.

\section{BIBLIOGRAPHY}

Biederman, D:E: (2007), Law and Business of the Entertainment Industries, Praeger Publishers, 5th ed.,

Brenner, T.A. (2005), "Quizzical” Look Into The Need For Reality Television Show Regulation, Cardozo Arts \& Ent. L.J.

Brett Bell, R., Odysseos, P. (2002), Sex, Drugs, and Court TV? How America's Increasing Interest in TrialPublicity Impacts Our Lawyers and the Legal System, 15 Geo. J. Legal Ethics.

Gies, L. (2008), Law and the Media: The Future of an Uneasy Relationship, Routledge Cavendish Taylor\&Francis Group.

Johnson Woods, T. (2002), Big Bother: why did that reality-tv show become such a phenomenon?, Lucia, UQP.

Podlas, K. Impact of Television on Cross-examination and Juror "truth", pp. 1-32. http://widenerlawreview.org/files/2009/06/06-podlas_final-483-511.pdf

Schwartz, S. (2011), Information Privacy Law, Wolters Kluwer, 4th ed,

\footnotetext{
${ }^{11}$ Kimberlianne Podlas, Impact of Television on Cross-examination and Juror "truth", p. 1-32. http:// widenerlawreview.org/files/2009/06/06-podlas_final-483-511.pdf

${ }^{12}$ Although disclaimer is a part of show, it is flashed on the screen in the manner that nothing can be read, unless it is paused and read. Therefore, there is a need for a stronger and longer manifestation of that im- portant difference.
} 
Scott Rau, A. (2005), „The Culture of American Arbitration and the Lessons of ADR“", Texas International Law Journal, The Center for Global Energy, International Arbitration, and Environmental Law. 